\title{
Structural Definition of Trehalose 6-Monomycolates and Trehalose 6,6'-Dimycolates from the Pathogen Rhodococcus equi by Multiple-Stage Linear lon-Trap Mass Spectrometry with Electrospray Ionization
}

\author{
Fong-Fu Hsu, ${ }^{1}$ Jens Wohlmann, ${ }^{2}$ John Turk, ${ }^{1}$ Albert Haas ${ }^{2}$ \\ ${ }^{1}$ Department of Internal Medicine, Mass Spectrometry Resource, Division of Endocrinology, Diabetes, Metabolism, and Lipid \\ Research, Washington University School of Medicine, 660 S Euclid, Box 8127, St. Louis, MO 63110, USA \\ ${ }^{2}$ Institute for Cell Biology, University of Bonn, Bonn, Germany
}

\begin{abstract}
The cell wall of the pathogenic bacterium Rhodococcus equi ( $R$. equi) contains abundant trehalose monomycolate (TMM) and trehalose dimycolate (TDM), the glycolipids bearing mycolic acids. Here, we describe multiple-stage $\left(\mathrm{MS}^{n}\right)$ linear ion-trap (LIT) mass spectrometric approaches toward structural characterization of TMM and TDM desorbed as $[\mathrm{M}+\mathrm{Alk}]^{+}(\mathrm{Alk}=\mathrm{Na}, \mathrm{Li})$ and as $[\mathrm{M}+\mathrm{X}]^{-}$ $\left(\mathrm{X}=\mathrm{CH}_{3} \mathrm{CO}_{2}, \mathrm{HCO}_{2}\right)$ ions by electrospray ionization (ESI). Upon $\mathrm{MS}^{n}(n=2,3,4)$ on the $[\mathrm{M}+\mathrm{Alk}]^{+}$or the $[\mathrm{M}+\mathrm{X}]^{-}$adduct ions of TMM and TDM, abundant structurally informative fragment ions are readily available, permitting fast assignment of the length of the meromycolate chain and of the $\alpha$-branch on the mycolyl residues. In this way, structures of TMM and TDM isolated from pathogenic $R$. equi strain 103 can be determined. Our results indicate that the major TMM and TDM molecules possess 6 , and/ or 6'-mycolyl groups that consist of mainly $\mathrm{C} 14$ and $\mathrm{C} 16$ a-branches with meromycolate branches ranging from $\mathrm{C} 18$ to $\mathrm{C} 28$, similar to the structures of the unbound mycolic acids found in the cell envelope. Up to 60 isobaric isomers varying in chain length of the a-branch and of the meromycolate backbone were observed for some of the TDM species in the mixture. This mass spectrometric approach provides a direct method that affords identification of various TMM and TDM isomers in a mixture of which the complexity of this lipid class has not been previously reported using other analytical methods.
\end{abstract}

Key words: Cord factor, Trehalose dimycolate, Trehalose monomycolate, mycolic acids, glycolipids, Rhodococcus equi, Internal glucose loss, Tandem mass spectrometry, ESI

\section{Introduction}

$\mathrm{R}$ hodococcus equi $(R$. equi) is a gram-positive intracellular pathogen that can cause severe bronchopneu-

Electronic supplementary material The online version of this article (doi:10.1007/s13361-011-0240-7) contains supplementary material, which is available to authorized users.

Correspondence to: Fong-Fu Hsu; e-mail: fhsu@im.wustl.edu monia in foals and in immunocompromised individuals such as patients with AIDS. It is one of the major causes of lung disease in foals between 1 and 6 mo of age [1-3]. The cell envelope contains many lipid species with unusual structures, including mycolic acids, trehalose monomycolate (TMM), and trehalose dimycolate (TDM) [4, 5].

TDM (or called cord factor) and TMM consist of a trehalose core to which two or one mycolic acid residue was esterified at $6,6^{\prime}$ or at 6 position to form trehalose $6,6^{\prime}$ - 
dimycolate (TDM) or trehalose 6-monomycolate (TMM), respectively (see Schemes 1 and 2). Mycolic acids are longchain $\alpha$-alkyl- $\beta$-hydroxy fatty acids produced by the mycolata, including the genera Corynebacterium, Mycobacterium, Nocardia, and Rhodococcus). The chain length ranges from 20 (shortest chains in corynebacteria) to more than 80 carbons (longest ones in mycobacteria), depending on the producing species. For example, $R$. equi strain 103 contains a homologous series of mycolic acids having chain length ranging from $\mathrm{C} 30$ to $\mathrm{C} 50$ with 0 to 2 double bonds [6], while mycolic acids from other strains have chain length between C24 and C48 with 0 to 4 double bonds [4]. During growth of Mycobacterium smegmatis in biofilms, TDM in cell envelope is hydrolyzed by a TDM-specific esterase to release free mycolic acids [7]. Mycolic acids, TDM and TMM, together with phospholipids such as cardiolipin, phosphatidylethanolamine, and phosphatidylinositol, as well as glycolipids such as phosphatidylinositol mannosides perform filler roles in completing the outer leaflet of the asymmetric lipid bilayer [8].

The biological activities of TDM and TMM in infection with pathogenic mycolata, including immunomodulation [9], granulomagenic activity [10], and the participation of TDM in the inhibition of phagosome-lysosome fusion have been well documented [11-13]. Pro-inflammatory cytokine production, granuloma formation, cachexia, and mortality can also be induced by $\operatorname{TDM}[10,14]$.

The traditional method for characterization of these complex lipids has been a difficult task, requiring laborious separation, purification, and chemical reaction, followed by spectroscopic analyses using IR, proton and carbon
NMR, and GC/MS [15-19]. Recently, a MALDI-TOF mass spectrometric approach has been used to determine the molecular masses of intact TMM [20] and TDM [21], and of the masses of the mycolic acid moieties as methyl esters following their release from TMM and TDM by hydrolysis. This approach requires TLC separation of the released mycolic acids into subclasses and does not provide structural information $[20,21]$. Here, we report a simple LIT ESI-MS ${ }^{n}$ method towards direct characterization of TMM and TDM isolated from the cell envelope of pathogenic Rhodococcus equi, revealing the numerous structures including the various isomers for each of the lipid species.

\section{Method}

\section{Sample Preparation}

$R$. equi strain 103, a virulent, plasmid-containing strain whose chromosomal DNA sequence has recently been reported was originally isolated from the lung of a pneumonic foal in Ontario, Canada [22], and was grown in $50 \mathrm{~mL}$ brain heart infusion broth $(\mathrm{BHI})$ at $37^{\circ} \mathrm{C}$, with shaking at $200 \mathrm{rpm}$ to an optical density $(600 \mathrm{~nm})$ of 1.0 and autoclaved at $121^{\circ} \mathrm{C}$ under $2.15 \mathrm{kPa}$ for $20 \mathrm{~min}$. Total lipids were extracted as previously described [6]. For further purification, $10 \mathrm{mg}$ of the crude lipid extracts in $300 \mathrm{ul}$ $\mathrm{CHCl}_{3} / \mathrm{CH}_{3} \mathrm{OH}(2: 1 ; \mathrm{vol} / \mathrm{vol})$, were loaded to a $3 \mathrm{~mL} /$ $200 \mathrm{mg}$ Macherey-Nagel amino Chromabond Sep-Pak column (Duren, Germany). The column was first washed with $2 \mathrm{~mL}$ EtOAc:Hexane (15:85 vol/vol), followed by

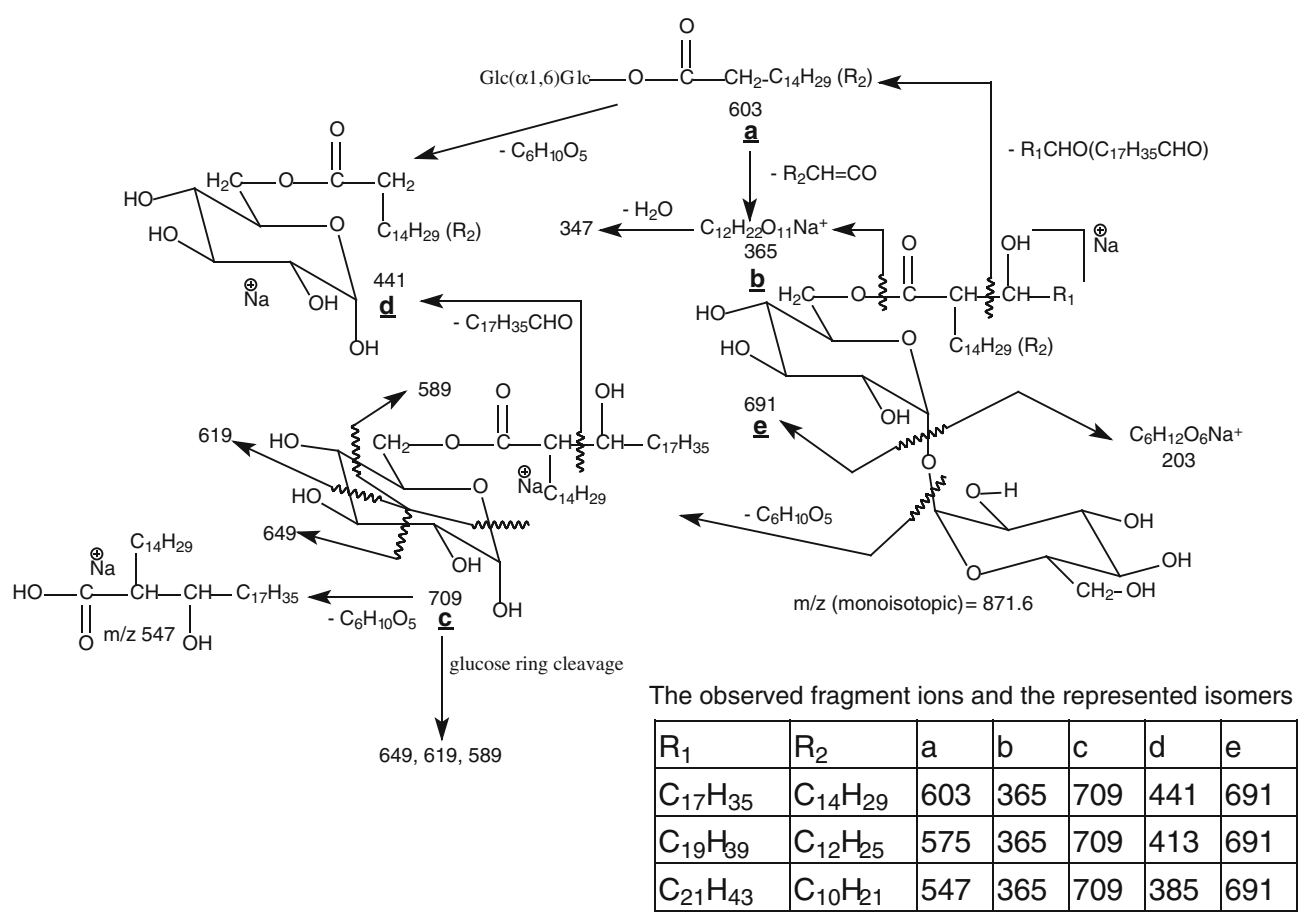

Scheme 1. The fragmentation pathways proposed for the $[\mathrm{M}+\mathrm{Na}]^{+}$ions of 6-mycolyl-a, $\alpha^{\prime}-\mathrm{D}$-trehalose (TMM) (the indicated $m / z$ values are ions seen for 18:0/16:0-TMM, which is one of the three isomers that give rise to the $[\mathrm{M}+\mathrm{Na}]^{+}$of $m / z$ 871) 


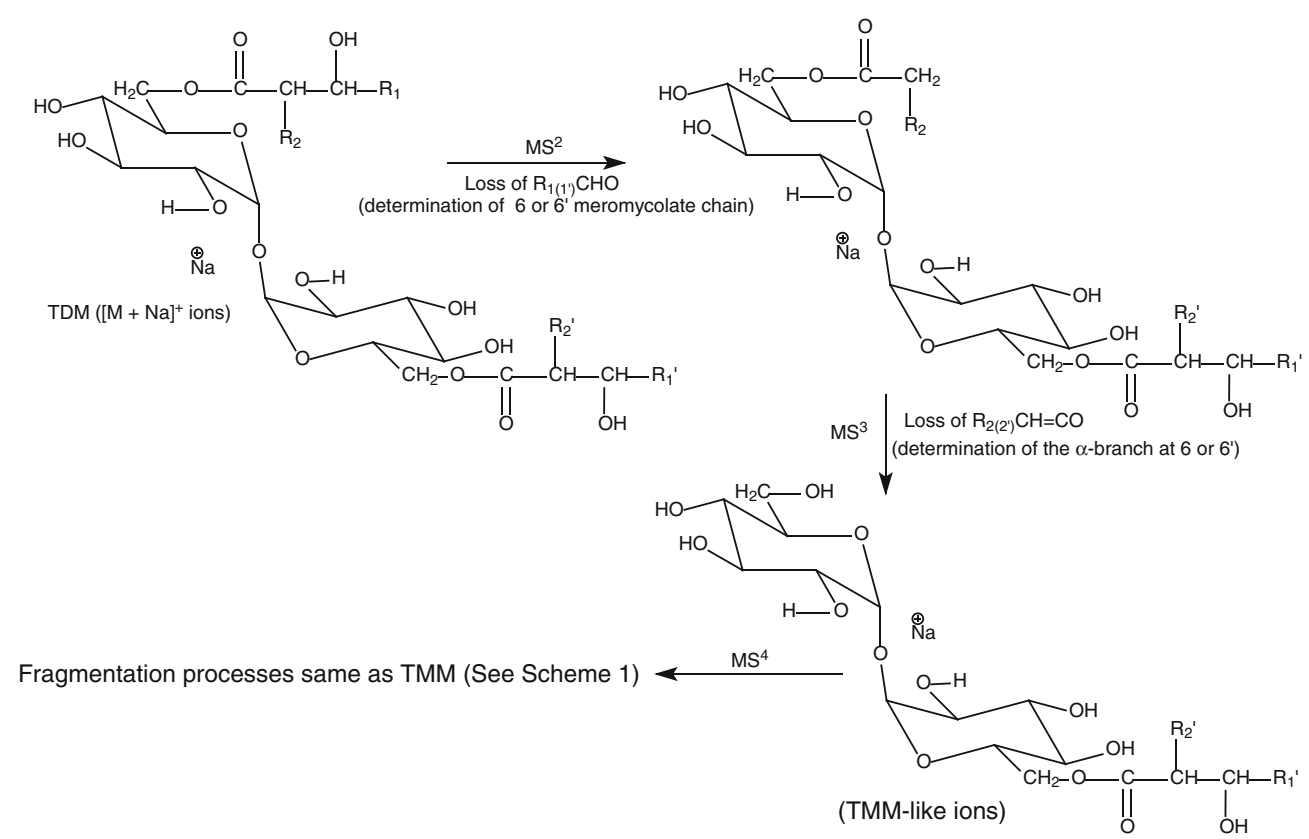

Scheme 2. The fragmentation tree applying multiple-stage mass spectrometry (MSn) for structural assignment of the $[\mathrm{M}+\mathrm{Na}]^{+}$ ions of 6,6'-dimycolyl-a, $\alpha^{\prime}-\mathrm{D}$-trehalose (TDM)

$1.5 \mathrm{~mL}$ di-isopropyl ether:HOAc (98:2; vol/vol), and then eluted with $2 \mathrm{~mL}$ acetone/methanol (9:1.35, vol/vol) (by gravity) to a vial. The eluant containing TDM and TMM was dried under a stream of nitrogen. The dried sample was redissolved in $\mathrm{CHCl}_{3} / \mathrm{CH}_{3} \mathrm{OH}(1 / 2)$ before ESI-MS analysis.

\section{Mass Spectrometry}

Low-energy CID $\mathrm{MS}^{n}$ experiments were conducted on a Thermo Finnigan (San Jose, CA, USA) linear ion-trap (LIT) mass spectrometer with Xcalibur (ver. 2.01) operating system. High resolution $(\mathrm{R}=100,000$ at $\mathrm{m} / \mathrm{z} 400)$ mass measurements on the $[\mathrm{M}+\mathrm{Na}]^{+}$ions of the TMM and TDM molecules and their subsequent $\mathrm{MS}^{n}$ fragment ions were performed on a Thermo LTQ Orbitrap Velos. TMM and TDM $(100 \mathrm{uL})$ from $R$. equi were dissolved in chloroform/methanol (1/2), and $\mathrm{CH}_{3} \mathrm{CO}_{2} \mathrm{Na}$ or $\mathrm{CH}_{3} \mathrm{CO}_{2} \mathrm{Li}$ $(2 \mu \mathrm{m})$ was added before infusion $(2 \mu \mathrm{L} / \mathrm{min})$ into the ESI source, where the skimmer was set at ground potential, the electrospray needle was set at $4.5 \mathrm{kV}$, and temperature of the heated capillary was $300{ }^{\circ} \mathrm{C}$. The automatic gain control of the ion trap was set to $5 \times 10^{4}$, with a maximum injection time of $200 \mathrm{~ms}$. Helium was used as the buffer and collision gas at a pressure of $1 \times 10^{-3}$ mbar $(0.75 \mathrm{mTorr})$. The mass resolution of the instrument was tuned to $0.6 \mathrm{Da}$ at half peak height. The $\mathrm{MS}^{n}$ experiments were carried out with an optimized relative collision energy ranging from $18 \%$ to $25 \%$ and with an activation $q$ value at 0.25 , and the activation time at 30-50 ms. Mass spectra were accumulated in the profile mode, typically for 3-10 $\min$ for $\operatorname{MS}^{n}(n=2,3$, 4 , and 5) spectra.

\section{Nomenclature}

The abbreviations previously used for mycolic acids were incorporated for designation of TMM and TDM. For example, the 2-tetradecyl-3-hydroxy-eicosanoic acid containing a $\mathrm{C}_{18}$-meromycolate chain and a $\mathrm{C}_{16} \alpha$-branch was designated as 18:0/16:0-mycolic acid [6]. Accordingly, trehalose monomycolate (TMM) having 18:0/16:0-mycolic acid attached to 6 (or 6') of the trehalose core, a 6-(2tetradecyl-3-hydroxy-eicosanoyl) trehalose is designated as 18:0/16:0-TMM. The (6)-2-tetradecyl-3-hydroxy-eicosanyl (6')-2-dodecyl-3-hydroxy-docosanyl-trehalose, which is a TDM containing a 18:0/16:0- and a 20:0/14:0-mycolyl groups at 6 and 6', respectively, is designated as (18:0/ 16:0-20:0/14:0)-TDM. There is no distinction among isomers in which the mycolyl groups attached to 6 or 6 are exchanged. Hence, for example, the structures of (18:0/ 16:0-20:0/14:0)-TDM and (20:0/14:0-18:0/16:0)-TDM are not distinguishable. There is no distinction between a cyclic chain and a double bond in the structural assignment. Hence, the designation of 18:1/16:0-TMM, for example, only signifies the unsaturated state of the $\mathrm{C}_{18}$-meromycolate chain is one.

\section{Results and Discussion}

TMM and TDM formed intense $[\mathrm{M}+\mathrm{Na}]^{+}$or $[\mathrm{M}+\mathrm{Li}]^{+}$ions when subjected to ESI in the presence of $\mathrm{Na}^{+}$or $\mathrm{Li}^{+}$in positive-ion mode. In the negative-ion mode in the presence of anions such as $\mathrm{CH}_{3} \mathrm{CO}_{2}{ }^{-}$or $\mathrm{HCO}_{2}{ }^{-}$, TMM and TDM formed $\left[\mathrm{M}+\mathrm{CH}_{3} \mathrm{CO}_{2}\right]^{-}$or $\left[\mathrm{M}+\mathrm{HCO}_{2}\right]^{-}$ions. As shown in Figure 1, the profiles of the ESI-MS spectra of the $[\mathrm{M}+\mathrm{Na}]^{+}$ 
(a)

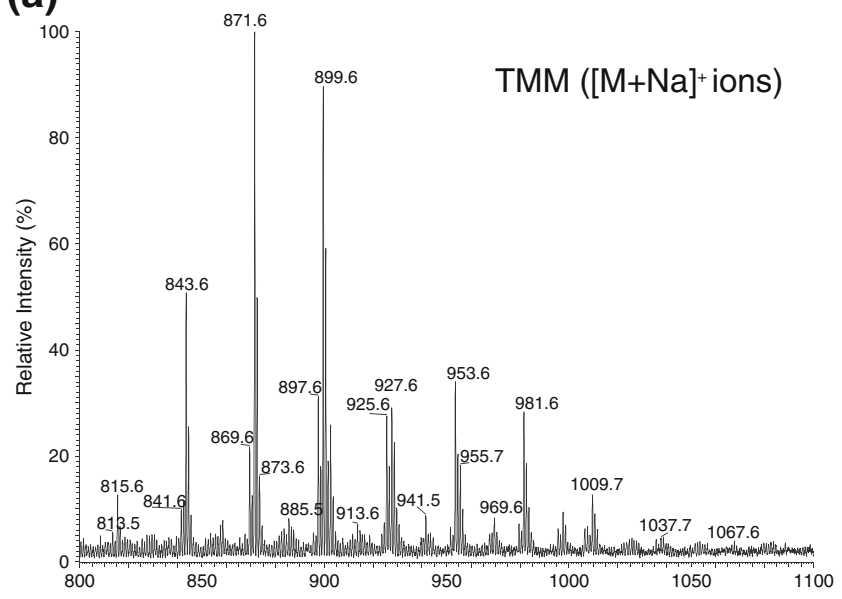

(b)

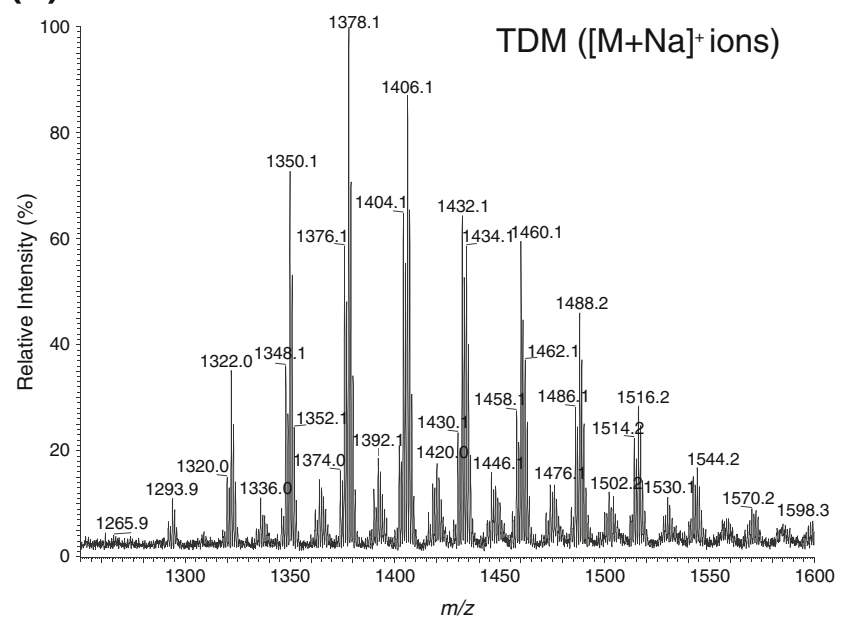

Figure 1. The ESI-MS spectra of the $[\mathrm{M}+\mathrm{Na}]^{+}$ions of TMM (a) and of TDM (b). These profiles are similar to their $\left[\mathrm{M}+\mathrm{CH}_{3} \mathrm{CO}_{2}\right]^{-}$ adduct ions (see Supplemental Material Figure S1)

ions of TMM (Figure 1a) and TDM (Figure 1b) isolated from $R$. equi, are nearly identical to those of the $\left[\mathrm{M}+\mathrm{CH}_{3} \mathrm{CO}_{2}\right]^{-}$ ions of the corresponding TMM (See supplemental Material, Figure S1a) and TDM (Figure S1b), respectively, indicating that the above adduct ions are applicable for profiling the TMM and TDM lipids. High-resolution mass measurements and structural characterization with LIT $\mathrm{MS}^{n}$ indicated that ion series with various numbers of unsaturated bonds are present and many isomers were identified for all the TMM and TDM species in the mixture (see Supplementary Material Table S1 and Table S2). The $\mathrm{MS}^{n}$ mass spectrometric approaches and the fragmentation processes leading to the structural characterization of TMM and TDM are described below.

\section{Characterization of TMM as $[\mathrm{M}+\mathrm{Na}]^{+}$or $[\mathrm{M}+\mathrm{Li}]^{+}$ Ions}

Upon CID, the $[\mathrm{M}+\mathrm{Na}]^{+}$ions of TMM yielded fragment ions corresponding to loss of the meromycolate chain (designated as a ion) (Scheme 1), loss of mycolic acid substituent as a ketene (b), as well as the sodiated ions of mycolylhexose (c) and of 6-acyl-glucose (mainly, 6-hexadecanoylglucose and 6-tetradecanoylglucose) (d). For example, the LIT MS ${ }^{2}$ spectrum of the base ion of $m / z 871$ (Figure 2a) is dominated by the ions at $\mathrm{m} / \mathrm{z} 709$ (loss of 162) (c), together with the ion at $m / z 691$ (loss of 180) (e) arising from loss of a glucose residue. The spectrum also contained the ions at $\mathrm{m} / \mathrm{z}$ 603, and 575 (a ions) arising from elimination of an eicosanal $\left(\mathrm{C}_{19} \mathrm{H}_{39} \mathrm{CHO}\right)$ and a doeicosanal $\left(\mathrm{C}_{21} \mathrm{H}_{43} \mathrm{CHO}\right)$ residues from the meromycolate chain, respectively. This is consistent with the observation of the ions at $\mathrm{m} / \mathrm{z} 441$ and 413 (d ions), representing the sodiated ions of hexadecanoylglucose (16:0-acyl glucose) and of tetradecanoylglucose (14:0-acyl glucose) arising from further loss of a glucose residue from $\mathrm{m} / \mathrm{z} 603$ and 575, respectively. The fragmentation processes were supported by the LIT MS $^{3}$ spectra of the ions of $m / z 603(871 \rightarrow 603$, Figure $2 b)$ and of $m / z 575(871 \rightarrow 575$, Figure S2a). The
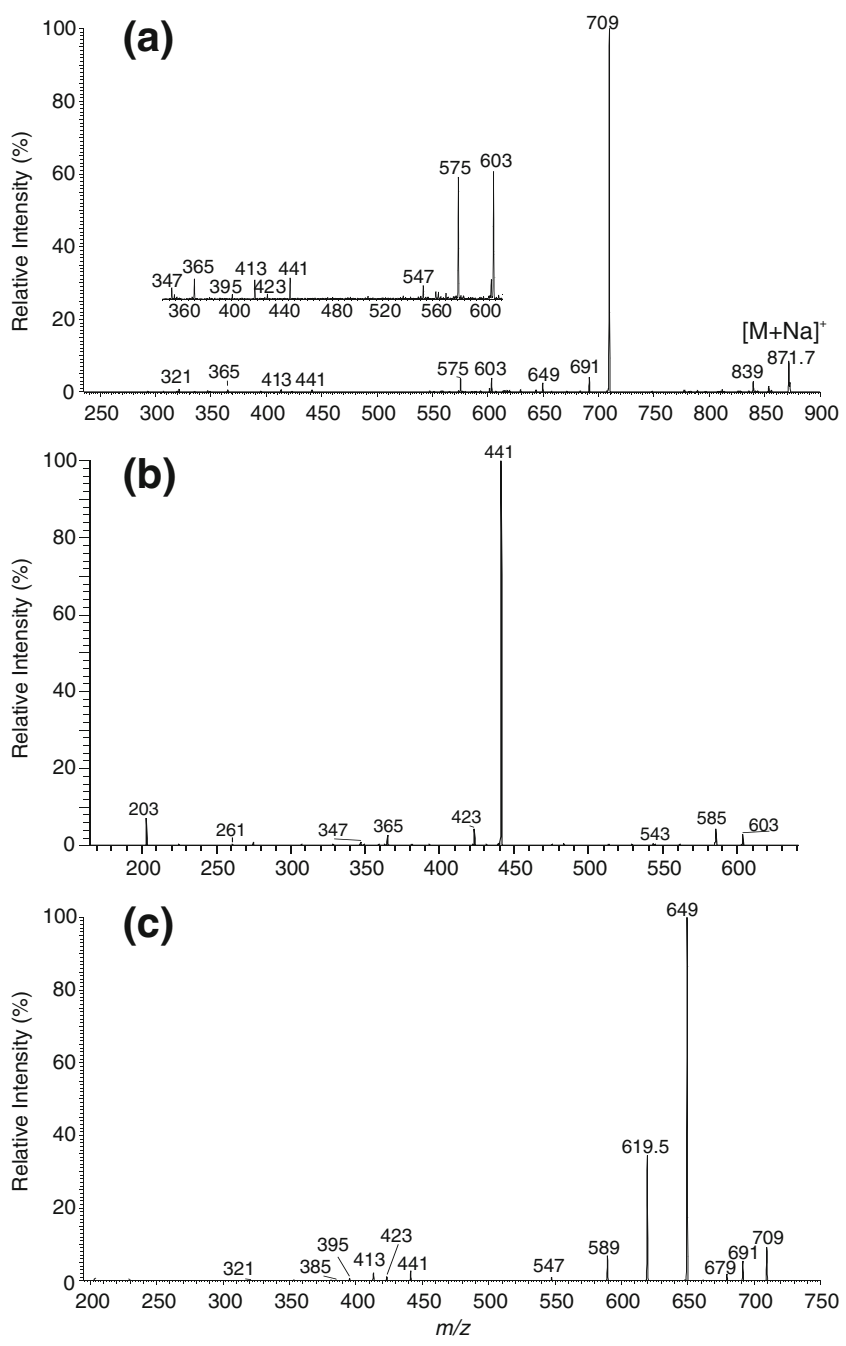

Figure 2. The LIT MS ${ }^{2}$ spectrum of the $[\mathrm{M}+\mathrm{Na}]^{+}$ion of TMM at $m / z 871$ (a), its $\mathrm{MS}^{3}$ spectra at $m / z 603(871 \rightarrow 603)(\mathbf{b})$, and at $m / z 709$ (871 $\rightarrow 709)$ (c) 
former spectrum is dominated by the ion at $m / z 441$, together with the sodiated trehalose ions at $\mathrm{m} / \mathrm{z} 365$ and 347 arising from losses of 16:0-fatty acid as a ketene and as an acid, respectively, and the sodiated glucose ion at $\mathrm{m} / \mathrm{z} 203$. The latter spectrum (Figure S2a) contained the analogous ions at $m / z 413$, along with ions at $m / z 365,347$, and 203. Further dissociation of the ion of $\mathrm{m} / \mathrm{z} 709(871 \rightarrow 709$, Figure 2c) gave rise to ions at $m / z 649,619$, and 589 , arising from bond cleavages across the hexose ring bearing the 6-mycolyl group (Scheme 1). The spectrum also contained the sodiated ions of 6-hexadecanoylglucose at $\mathrm{m} / \mathrm{z} 441$ and of 6tetradecanoylglucose at $\mathrm{m} / \mathrm{z} 413$, arising from losses of an octadecanal $\left(\mathrm{C}_{17} \mathrm{H}_{35} \mathrm{CHO}\right)$ and an eicosanal $\left(\mathrm{C}_{19} \mathrm{H}_{39} \mathrm{CHO}\right)$ residues, respectively. The results indicate that the ion at $\mathrm{m} / \mathrm{z}$ 709 represents both a sodiated ions of 6-(2-tetradecyl-3hydroxy-eicosanyl)-glucose (18:0/16:0-Glc) and of 6-(2dodecyl-3-hydroxy-docosanyl)-glucose (20:0/14:0-Glc) (Table 1). The results indicate that the ion of $\mathrm{m} / \mathrm{z} 871$ mainly represents a 6-(2-tetradecyl-3-hydroxy-doeicosanoyl) trehalose (18:0/16:0-TMM) and a 6-(2-dodecyl-3-hydroxytetraeicosanoyl) trehalose (20:0/14:0-TMM).

Table 1. Structures of the Sodiated Mycolyl Glucoside Ions Revealed by MS ${ }^{n}$

\begin{tabular}{|c|c|c|c|}
\hline \multirow{2}{*}{$\begin{array}{l}{[\mathrm{M}+\mathrm{Na}]^{+}} \\
\mathrm{m} / \mathrm{z}\end{array}$} & \multirow{2}{*}{$\begin{array}{l}\text { Mycolic acid } \\
\text { compositions }\end{array}$} & \multicolumn{2}{|c|}{$\begin{array}{l}\text { Isomeric structures } \\
\text { (meramycolate/ } \alpha \text {-branch) }\end{array}$} \\
\hline & & major isomers & minor isomers \\
\hline 901 & $48: 2$ & $32: 1 / 16: 1$ & \\
\hline 875 & $46: 1$ & $30: 1 / 16: 0 ; 32: 1 / 14: 0$ & \\
\hline 873 & $46: 2$ & $30: 1 / 16: 1 ; 30: 2 / 16: 0$ & $32: 2 / 14: 0 ; 28: 2 / 18: 0$ \\
\hline 863 & $45: 0$ & $29: 0 / 16: 0 ; 31: 0 / 14: 0$ & \\
\hline 861 & $45: 1$ & $31: 1 / 14: 0 ; 29: 1 / 16: 0$ & \\
\hline 847 & $44: 1$ & $28: 1 / 16: 0 ; 30: 1 / 14: 0$ & \\
\hline 845 & $44: 2$ & $28: 1 / 16: 0$ & \\
\hline 835 & $43: 0$ & $27: 0 / 16: 0$ & $26: 0 / 17: 0$ \\
\hline 819 & $42: 1$ & $26: 1 / 16: 0 ; 28: 1 / 14: 0$ & \\
\hline 817 & $42: 2$ & $28: 1 / 14: 1 ; 26: 1 / 16: 1$ & $28: 2 / 14: 0 ; 26: 2 / 18: 0$ \\
\hline 807 & 41:0 & $25: 0 / 16: 0 ; 26: 0 / 15: 0$ & $24: 0 / 17: 0$ \\
\hline 805 & $41: 1$ & $26: 1 / 15: 0$ & \\
\hline 793 & $40: 0$ & $24: 0 / 16: 0 ; 26: 0 / 14: 0$ & \\
\hline 789 & $40: 2$ & $24: 1 / 16: 1 ; 26: 1 / 14: 1$ & \\
\hline 791 & $40: 1$ & $24: 1 / 16: 0 ; 26: 1 / 14: 0$ & $28: 1 / 12: 0$ \\
\hline 779 & $39: 0$ & $24: 0 / 15: 0$ & $23: 0 / 16: 0$ \\
\hline 777 & $39: 1$ & $24: 1 / 15: 0$ & \\
\hline 765 & $38: 0$ & $22: 0 / 16: 0 ; 24: 0 / 14: 0$ & 20:0/18:0 \\
\hline 763 & $38: 1$ & $22: 1 / 16: 0 ; 24: 1 / 14: 0$ & \\
\hline 761 & $38: 2$ & $24: 1 / 14: 1 ; 22: 1 / 16: 1$ & \\
\hline 751 & $37: 0$ & $21: 0 / 16: 0 ; 20: 0 / 17: 0$ & $22: 0 / 15: 0$ \\
\hline 749 & $37: 1$ & $22: 1 / 15: 0 ; 20: 1 / 17: 0$ & $24: 1 / 13: 0$ \\
\hline 737 & $36: 0$ & $20: 0 / 16: 0 ; 22: 0 / 14: 0$ & $18: 0 / 18: 0$ \\
\hline 735 & $36: 1$ & $20: 1 / 16: 0 ; 22: 1 / 14: 0$ & $20: 0 / 16: 1 ; 18: 0 / 18: 1$ \\
\hline 723 & $35: 0$ & $20: 0 / 15: 0 ; 18: 0 / 17: 0$ & $19: 0 / 16: 0$ \\
\hline 721 & $35: 1$ & $20: 0 / 15: 1$ & \\
\hline 709 & $34: 0$ & $20: 0 / 14: 0 ; 18: 0 / 16: 0$ & \\
\hline 707 & $34: 1$ & $20: 1 / 14: 0 ; 18: 0 / 16: 1$ & $\begin{array}{l}20: 0 / 14: 1 ; 18: 1 / 16: 0 ; \\
22: 1 / 12: 0\end{array}$ \\
\hline 705 & $34: 2$ & $20: 1 / 14: 1 ; 19: 2 / 15: 0$ & \\
\hline 695 & $33: 0$ & $18: 0 / 15: 0 ; 20: 0 / 13: 0$ & \\
\hline 693 & $33: 1$ & $18: 1 / 15: 0$ & \\
\hline 681 & $32: 0$ & $18: 0 / 14: 0 ; 20: 0 / 12: 0$ & \\
\hline 679 & $32: 1$ & $18: 0 / 14: 1$ & \\
\hline 677 & $32: 2$ & $18: 1 / 14: 1$ & \\
\hline 667 & $31: 0$ & $18: 0 / 13: 0$ & \\
\hline 653 & $30: 0$ & $18: 0 / 12: 0$ & \\
\hline 651 & $30: 1$ & $18: 0 / 12: 1$ & \\
\hline
\end{tabular}

In Figure 2a, a minor ion at $\mathrm{m} / \mathrm{z} 547$ arising from loss of tetraeicosanal is also present. This ion together with the minor ion of $\mathrm{m} / \mathrm{z} 385$ representing a sodiated 12:0-acyl glucose cation seen in Figure 2c indicates that the ion of $\mathrm{m} / \mathrm{z}$ 871 also represents a minor 22:0/12:0-TMM isomer. The $\mathrm{MS}^{3}$ spectrum of the ion of $\mathrm{m} / \mathrm{z} 547(871 \rightarrow 547$, not shown) is dominated by the ion at $\mathrm{m} / \mathrm{z} 385$, consistent with the presence of the 22:0/12:0-TMM isomer.

The above structural assignment is further confirmed by LIT $\mathrm{MS}^{2}$ on the corresponding $[\mathrm{M}+\mathrm{Li}]^{+}$ion at $m / z 855$ (Figure S2b), which yielded prominent ion at $\mathrm{m} / z 693$ (loss of 162), together with ions at $\mathrm{m} / \mathrm{z} 675$ (loss of 180), 603, $587,559,531$, and 349 . These ions are $16 \mathrm{Da}$ lighter than those seen in Figure 2a, and are the lithiated analogs arising from the same fragmentation processes. The profile of the $\mathrm{MS}^{3}$ spectrum of the ion at $\mathrm{m} / \mathrm{z} 693(855 \rightarrow 693$; Figure S2c) is similar to that seen in Figure 2c, and the ions at $\mathrm{m} / \mathrm{z}$ 675, $633,603,573,425,397$, and 369 are also16 Da lighter than the sodiated analogs. The results further support the fragmentation processes (Scheme 1) and the assignment of the major isomers of 18:0/16:0-TMM and 20:0/14:0-TMM and the minor 22:0/12:0-TMM isomer.

Structural characterization of the $[\mathrm{M}+\mathrm{Na}]^{+}$ions of TMM with unsaturated bond(s) is exemplified by $\mathrm{MS}^{n}$ on the ion of $m / z 1009$, which consisted of one unsaturated bond (Table $\mathrm{S} 1$ ). The $\mathrm{MS}^{2}$ spectrum of the ion of $\mathrm{m} / \mathrm{z} 1009$ (see Supplemental Material, Figure S3a) contained the prominent ion at $\mathrm{m} / \mathrm{z} 847$ (loss of 162), and the ion of $\mathrm{m} / \mathrm{z} 829$ (loss of 180 ), arising from loss of a glucose residue. The ions at $\mathrm{m} / \mathrm{z}$ 603 and 575 arise from loss of unsaturated octaeicosenal and tricosenal, respectively, indicating that the unsaturated bond is located at the $\mathrm{C}_{27}$ - or $\mathrm{C}_{29}$-meromycolate chain. The ion at $\mathrm{m} / \mathrm{z} 603$ was formed together with the ions at $\mathrm{m} / \mathrm{z} 441$ (loss of 162) and 423 (loss of 180), arising from the 28:1/16:0TMM isomer; while the ions of $m / z 575,413$, and 395 arose from the analogous losses from the 30:1/14:0-TMM isomer. The assignments were further supported by $\mathrm{MS}^{3}$ on the ion of $m / z 847(1009 \rightarrow 847)$ (Figure S3b), which yielded ions at $\mathrm{m} / \mathrm{z} 829,787,757$, and 727 , arising from cleavages of the glucose ring, and the ions at $\mathrm{m} / \mathrm{z} 443$ and 413 , arising from further losses of $\mathrm{C}_{27} \mathrm{H}_{53} \mathrm{CHO}$ and $\mathrm{C}_{29} \mathrm{H}_{57} \mathrm{CHO}$, respectively. The results support that the ion of $\mathrm{m} / z 1009$ represents both a 28:1/16:0-TMM and 30:1/14:0-TMM isomers, which possess unsaturated meromycolate chain.

The sodiated TMM ions containing two unsaturated bonds were seen at $\mathrm{m} / \mathrm{z} 923,951,979,1007$, and 1035 (Table S1). The profiles of the $\mathrm{MS}^{2}$ spectrum of the ion at $\mathrm{m} /$ $z 979$ (Figure S3c) and of the $\mathrm{MS}^{3}$ spectrum of the ion at $\mathrm{m} / \mathrm{z}$ $817(979 \rightarrow 817$; Figure S3d) are similar to those seen in Figure S3a and S3b. However, the major sodiated acylglucose ion is seen at $\mathrm{m} / \mathrm{z} 439$ (Figure S3d), representing a sodiated 16:1-acyl glucose ion arising from loss of $\mathrm{C}_{25} \mathrm{H}_{49} \mathrm{CHO}$. The results indicate that the ion represents mainly a 26:1/16:1-TMM isomer, which possesses an unsaturated bond in both the meromycolate and $\alpha$-alkyl chains. This structure assignment is also consistent with the 
observation of the ion at $m / z 601$ in Figure S3c, arising from loss of $\mathrm{C}_{25} \mathrm{H}_{49} \mathrm{CHO}$ residue. In Figure $\mathrm{S} 3 \mathrm{~d}$, minor ions at $\mathrm{m} / \mathrm{z}$ 441 (16:0-acyl glucose) and 413 (14:0-acyl glucose) arising from losses of $\mathrm{C}_{25} \mathrm{H}_{47} \mathrm{CHO}$ and $\mathrm{C}_{27} \mathrm{H}_{51} \mathrm{CHO}$, respectively, are also present. The presence of these ions are consistent with the observation of the ions of $\mathrm{m} / z 575$ and 603, arising from loss of $\mathrm{C}_{27} \mathrm{H}_{51} \mathrm{CHO}$ and $\mathrm{C}_{25} \mathrm{H}_{47} \mathrm{CHO}$, respectively. The results indicate the presence of the minor isomers of 26:2/16:0-TMM and 28:2/14:0-TMM, of which the unsaturated bonds are located at the meromycolate chain, and the $\alpha$-alkyl group is saturated.

The above results demonstrated the utility of $\mathrm{MS}^{n}$ in the identification of TMM molecules including the information of distribution of double bond(s) in $\alpha$-alkyl or meromycolate chain.

\section{Characterization of TDM as $[\mathrm{M}+\mathrm{Na}]^{+}$Ions}

The isomeric structures grew immensely for TDM because the presence of an additional mycolyl group as compared to TMM. Scheme 2 summarized the multiple-stage mass spectrometric approaches toward the structural elucidation of TDM as the $[\mathrm{M}+\mathrm{Na}]^{+}$ions in this study. The LIT MS ${ }^{n}$ on the $[\mathrm{M}+\mathrm{Na}]^{+}$ion also yielded fragment ions corresponding to loss of the meromycolate chain (designated as a and a' ion) (Scheme 3), loss of the mycolic acid substituent as a ketene ( $\underline{b}$ and $\left.\underline{b}^{\prime}\right)$, together with the sodiated ions of mycolylhexose (들 and $\underline{c}^{\prime}$ ) and of acyl-hexose (mainly hexadecanoyl- or tetradecanoyl-hexose) ( $\underline{\mathrm{d}}$ and $\left.\underline{\mathrm{d}}^{\prime}\right)$ similar to those seen for TMM.

For example, the LIT MS ${ }^{2}$ spectrum of the ion at $\mathrm{m} / \mathrm{z}$ 1378 (Figure 3a) contained major ions at $m / z 1109$ (a) and 1081 (a') arising from loss of an octadecanal and an eicosanal residues from the meromycolate chain, respectively, along with the ions at $m / z 899$ (b) and 871 (b'), arising from losses of 2-dodecyl-3-hydroxy-eicosanoic acid and 2-tetradecyl-3-hydroxy-eicosanoic acid (or 2-dodecyl-3hydroxy-docosanoic acid) as ketenes, respectively; while the ions at $\mathrm{m} / \mathrm{z} 709,737$, and 681 represent the sodiated ions of mycolylglucose. Further dissociation of the ion of $\mathrm{m} / \mathrm{z} 1109$ $(1378 \rightarrow 1109$, Figure $3 b)$ led to ions at $m / z$ 927, $899($ b) , and $871\left(\underline{b}^{\prime}\right)$, which are equivalent to the sodiated TMM ions arising from further losses of 12:0-, 14:0-, and 16:0-fatty acyl acids as ketenes, respectively. The ions at $m / z$ 841, 813, and 785 arise from elimination of an octadecanal $\left(\mathrm{C}_{17} \mathrm{H}_{35} \mathrm{CHO}\right)$, eicosanal $\left(\mathrm{C}_{19} \mathrm{H}_{39} \mathrm{CHO}\right)$ or a docosanal $\left(\mathrm{C}_{21} \mathrm{H}_{43} \mathrm{CHO}\right)$ residue from the remaining mycolyl group and represent mainly the sodiated 6,6'-dihexadecanoyltrehalose, 6-hexadecanoly-6'-tetradecanoyl-trehalose, and 6,6'-ditetradecanoyl-trehalose, respectively. These diacyltrehalose structures were confirmed by observation of the prominent acylglucose ions at $\mathrm{m} / \mathrm{z} 441$ and 413 in the $\mathrm{MS}^{4}$ spectrum of the ion of $\mathrm{m} / \mathrm{z} 813 \quad(1378 \rightarrow 1109 \rightarrow 813$;

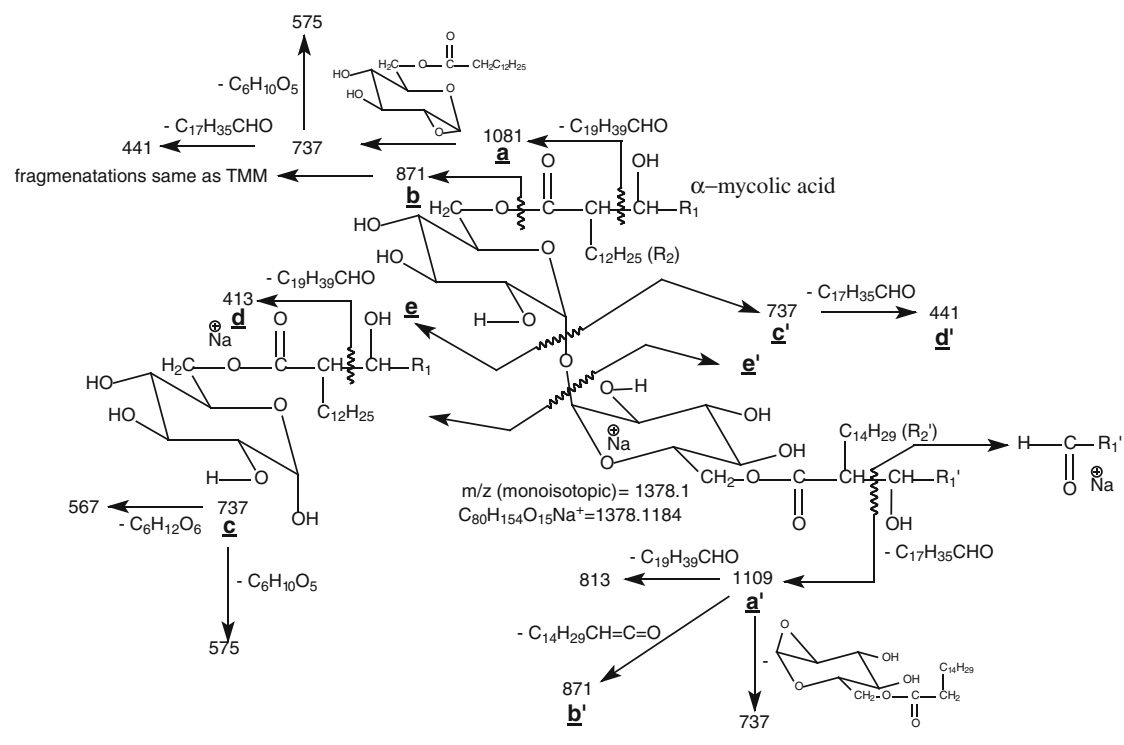

The major composition of meromycolate and $\alpha$-branches seen
\begin{tabular}{|l|l|l|l|}
\hline $\mathrm{R}_{1}$ & $\mathrm{R}_{2}$ & $\mathrm{R}_{1}{ }^{\prime}$ & $\mathrm{R}_{2}{ }^{\prime}$ \\
\hline $\mathrm{C}_{19} \mathrm{H}_{39}$ & $\mathrm{C}_{12} \mathrm{H}_{25}$ & $\mathrm{C}_{17} \mathrm{H}_{35}$ & $\mathrm{C}_{14} \mathrm{H}_{29}$ \\
\hline $\mathrm{C}_{17} \mathrm{H}_{35}$ & $\mathrm{C}_{14} \mathrm{H}_{29}$ & $\mathrm{C}_{17} \mathrm{H}_{35}$ & $\mathrm{C}_{14} \mathrm{H}_{29}$ \\
\hline $\mathrm{C}_{19} \mathrm{H}_{39}$ & $\mathrm{C}_{12} \mathrm{H}_{25}$ & $\mathrm{C}_{19} \mathrm{H}_{39}$ & $\mathrm{C}_{12} \mathrm{H}_{25}$ \\
\hline
\end{tabular}

Scheme 3. The fragmentation pathways proposed for the $[\mathrm{M}+\mathrm{Na}]^{+}$ions of $6,6^{\prime}$-dimycolyl-a, $\alpha^{\prime}$-D-trehalose (TDM). The indicated $\mathrm{m} / \mathrm{z}$ values are fragment ions seen for (20:0/14:0-18:0/16:0-TDM isomer, which is one of the major isomers that represent the sodiated molecular species of $\mathrm{m} / \mathrm{z} 1378.1$ 

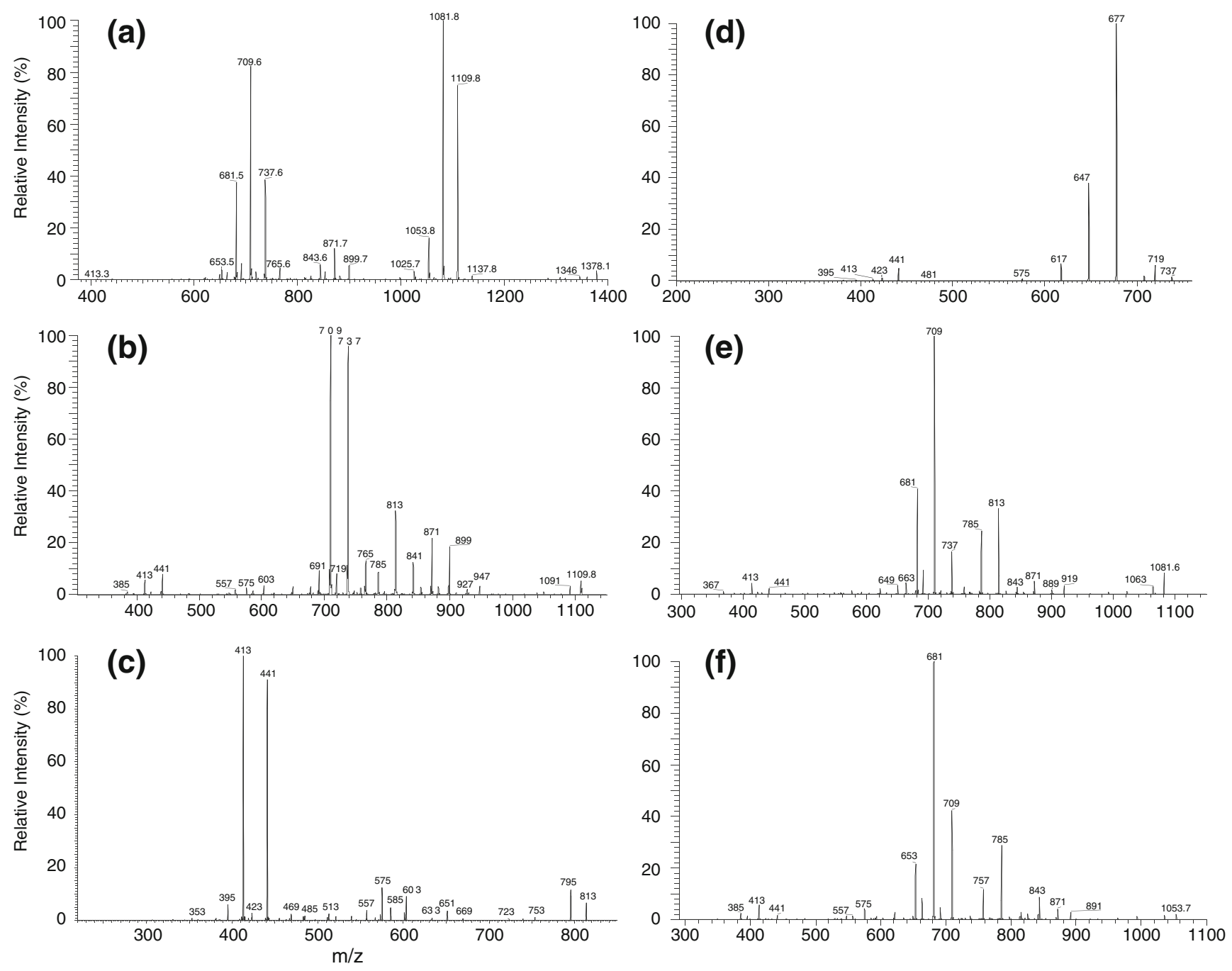

Figure 3. The LIT MS ${ }^{2}$ spectrum of the $[\mathrm{M}+\mathrm{Na}]^{+}$ion of TDM at $m / z 1378$ (a), its $\mathrm{MS}^{3}$ spectra at $\mathrm{m} / z$ 1109 (1378 $\left.\rightarrow 1109\right)(\mathbf{b})$, its MS $^{4}$ spectra at $m / z 813(1378 \rightarrow 1109 \rightarrow 813)(\mathbf{c})$, and at $\mathrm{m} / z 737(1378 \rightarrow 1109 \rightarrow 737)(\mathbf{d})$; the $\mathrm{MS}^{3}$ spectra of the ions of $\mathrm{m} / \mathrm{z} 1081$ $(1378 \rightarrow 1081)(\mathbf{e})$, and of $\mathrm{m} / \mathrm{z} 1053(1378 \rightarrow 1053)(\mathbf{f})$

Figure 3c) and the ions of $m / z 441$ and 413, respectively, in the $\mathrm{MS}^{4}$ spectra of the ions of $\mathrm{m} / \mathrm{z} 841$ and of 785 (data not shown). The ions at $m / z 709,737$, and 765 (Figure 3b) arose mainly from further loss of a glucose residue (loss of $162 \mathrm{Da}$ ) from ions of $\mathrm{m} / \mathrm{z} 871,899$, and 927 , respectively. Both the $\mathrm{MS}^{3}$ spectrum of the ion of $\mathrm{m} / z 871(1378 \rightarrow 871)$ and the $\mathrm{MS}^{4}$ spectrum of the ion of $\mathrm{m} / \mathrm{z} 871(1378 \rightarrow 1109 \rightarrow 871)$ (not shown) are identical to the $\mathrm{MS}^{2}$ spectrum of the TMM ion of $\mathrm{m} / \mathrm{z} 871$ shown earlier (Figure 2a), consistent with the notion that the ions of $\mathrm{m} / \mathrm{z}$ 871, 927, and 899 seen in Figure $3 \mathrm{~b}$ are equivalent to the sodiated TMM ions.

The LIT MS ${ }^{4}$ spectrum of the ion of $\mathrm{m} / z 709(1378 \rightarrow$ $1109 \rightarrow 709)$ and the $\mathrm{MS}^{5}$ spectrum of the ion at $\mathrm{m} / \mathrm{z} 709$ $(1378 \rightarrow 1109 \rightarrow 871 \rightarrow 709)$ (not shown) are similar to the spectrum shown in Figure 2c, in agreement with the notion that the ion of $m / z 709$ arises from further loss of a glucose residue from $\mathrm{m} / \mathrm{z}$ 871. The results indicate that $\mathrm{m} / \mathrm{z} 709$ represents both a sodiated ions of 20:0/14:0-Glc and of 18:0/
16:0-Glc (Table 1). The combined structural information shows that the ion at $m / z 1378$ mainly represents a (6)-2tetradecyl-3-hydroxy-eicosanyl (6')-2-dodecyl-3-hydroxydocosanyl-trehalose ((18:0/16:0-20:0/14:0)-TDM) (i.e., $\mathrm{R}_{1}$ $=\mathrm{C}_{17} \mathrm{H}_{35}, \mathrm{R}_{2}=\mathrm{C}_{14} \mathrm{H}_{29}, \mathrm{R}_{1}{ }^{\prime}=\mathrm{C}_{19} \mathrm{H}_{39}, \mathrm{R}_{2}{ }^{\prime}=\mathrm{C}_{12} \mathrm{H}_{25}$ ) and a (6)2-tetradecyl-3-hydroxy-eicosanyl, (6')-2-tetradecyl-3hydroxy-eicosanyl-trehalose (18:0/16:0-18:0/16:0)-TDM) (i.e., $\mathrm{R}_{1}=\mathrm{C}_{17} \mathrm{H}_{35}, \mathrm{R}_{2}=\mathrm{C}_{14} \mathrm{H}_{29}, \mathrm{R}_{1}{ }^{\prime}=\mathrm{C}_{17} \mathrm{H}_{35}, \mathrm{R}_{2}{ }^{\prime}=\mathrm{C}_{14} \mathrm{H}_{29}$ ) (Scheme 3).

The LIT MS ${ }^{5}$ spectrum of the ion of $m / z 737(1378 \rightarrow$ $1109 \rightarrow 899 \rightarrow 737$ ) (Figure 3d) contained the ions at $m / z 719$, 677,647 , and 617, arising from bond cleavages across the hexose ring bearing the 6-mycolyl group, and the sodiated acylglucose ions at $\mathrm{m} / \mathrm{z} 441$ and 413 , indicating that the $\mathrm{m} / \mathrm{z}$ 737 ion represents both a sodiated 2-tetradecyl-3-hydroxydocosanyl-6'-glucose (20:0/16:0-Glc) and dodecyl-3hydroxy-tetracosanyl-6'-glucose (22:0/14:0-Glc). The combined information demonstrates that the ion of $m / z 1378$ also 
represents a (6)-2-dodecyl-3-hydroxy-eicosanyl, (6')-2-tetradecyl-3-hydroxy-docosanyl-trehalose ((18:0/14:0-20:0/16:0)TDM) and a minor (18:0/14:0-22:0/14:0)-TDM isomer. The LIT $\mathrm{MS}^{5}$ spectrum of the ion of $\mathrm{m} / \mathrm{z} 765(1378 \rightarrow 1109 \rightarrow$ $927 \rightarrow 765$; Table 1) contained ion at $m / z$ 441, suggesting the presence of a minor isomer of (18:0/12:0-22:0/16:0)TDM.

In Figure 3b, the ion at $\mathrm{m} / \mathrm{z} 947$ corresponding to loss of a glucose residue (loss of $162 \mathrm{Da}$ ) is also present, indicating a glucose residue had been cleaved from $\mathrm{m} / \mathrm{z}$ 1109. High resolution mass spectrometry confirms that this loss is indeed a hexose residue (Table S3). The $\mathrm{MS}^{3}$ spectrum of $m / z 947(1378 \rightarrow 1109 \rightarrow 947$; data not shown) contained ions at $\mathrm{m} / \mathrm{z} 651$ (loss of $\mathrm{C}_{19} \mathrm{H}_{39} \mathrm{CHO}$ ) and 691 (loss of 16:0 fatty acid), indicating that the ion of $\mathrm{m} / \mathrm{z} 947$ contains a 20:0/ 14:0-mycolyl and a 16:0-fatty acyl groups attached to a glucose residue. Similar internal loss of glucose also resulted in the formation of the ions of $\mathrm{m} / \mathrm{z} 919$ (Figure 3e) and $\mathrm{m} / \mathrm{z}$ 891 (Figure 3f) seen in the later analogous $\mathrm{MS}^{3}$ spectra; and this unusual hexose loss has been previously reported [23-27].

Further dissociation of the ion of $\mathrm{m} / \mathrm{z} 1081(1378 \rightarrow 1081$, Figure 3e) gave rise to ions at $\mathrm{m} / \mathrm{z} 899,871$, and 843 , arising from losses of 12:0-, 14:0-, and 16:0-fatty acyl ketenes, respectively. The ion at $\mathrm{m} / \mathrm{z} 919$ arose from internal loss of glucose (loss of $162 \mathrm{Da}$ ) as seen earlier; while ions at $\mathrm{m} / \mathrm{z}$ 813 and 785 arose from further losses of a $\mathrm{C}_{17} \mathrm{H}_{35} \mathrm{CHO}$ or a $\mathrm{C}_{19} \mathrm{H}_{39} \mathrm{CHO}$ residue from meromycolate chain of the remaining mycolyl group. The spectrum also contained ions at $\mathrm{m} / z 737$ and 709, and 681, arising from further loss of a glucose residue (loss of $162 \mathrm{Da}$ ) from ions at $\mathrm{m} / \mathrm{z} 899,871$, and 843 , respectively. The LIT MS ${ }^{5}$ spectra of the ions of $\mathrm{m} / \mathrm{z}$ $709(1378 \rightarrow 1081 \rightarrow 871 \rightarrow 709)$ and of $737(1378 \rightarrow 1081 \rightarrow$ $899 \rightarrow 737$ ) (data not shown) are identical to those shown earlier (Figures $2 \mathrm{c}$ and $3 \mathrm{~d}$ ). The combined structural information from the $\mathrm{MS}^{3}$ spectrum of $\mathrm{m} / \mathrm{z} 1081, \mathrm{MS}^{4}$ spectrum of $\mathrm{m} / \mathrm{z}$ 899 , and $\mathrm{MS}^{5}$ spectrum of $\mathrm{m} / \mathrm{z} 737$ led to assignment of the (20:0/12:0-20:0/16:0)-TDM isomer (1081-899-737 series); while structural information from $\mathrm{MS}^{n}$ on 1081,871 , and 709 (1081-871-709 series) gave assignment of isomers of (20:0/14:0-18:0/16:0)-TDM and (20:0/14:0-20:0/14:0)TDM. Similarly, the LIT MS ${ }^{5}$ spectrum of the ion of $\mathrm{m} / \mathrm{z} 681$ $(1378 \rightarrow 1081 \rightarrow 843 \rightarrow 681)$ (data not shown) contained ions at $\mathrm{m} / \mathrm{z} 651,621,591$, and 561 , arising from cleavages of the glucose ring and ions at $\mathrm{m} / \mathrm{z} 413$ (sodiated 14:0-acyl glucose) and 385 (sodiated 12:0-acyl glucose), from losses of $\mathrm{C}_{17} \mathrm{H}_{35} \mathrm{CHO}$ and $\mathrm{C}_{19} \mathrm{H}_{39} \mathrm{CHO}$, suggesting that the ion at $\mathrm{m} / \mathrm{z} 681$ represents both a sodiated 18:0/14:0Glc and 20:0/12:0-Glc ions (Table 1). These structural information (1081-841-681 series) confirms the formerly assigned (20:0/16:0-18:0/14:0)-TDM and 20:0/16:0-20:0/ 12:0)-TDM structures.

$\mathrm{MS}^{3}$ on the ion of $m / z 1053(1378 \rightarrow 1053)$ (Figure $3 \mathrm{f}$ ) yielded ions at $\mathrm{m} / \mathrm{z} 871,843$, and 815 by losses of 12:0-, 14:0-, and 16:0-fatty acyl ketene, respectively; and the ions at $m / z 709,681$, and 653 arose from further loss of a glucose residue. The ions of $m / z 709$ and 681 consist of the same structures defined earlier and the ion at $\mathrm{m} / \mathrm{z} 653$ represents a sodiated 18:0/12:0-Glc (Table 1). These structural information identifies (22:0/12:0-18:0/16:0)-TDM, (22:0/12:0-20:0/ 14:0)-TDM (1053-871-709 series); (22:0/14:0-18:0/14:0)TDM, (22:0/14:0-20:0/12:0)-TDM (1053-843-681 series); and the (22:0/16:0-18:0/12:0)-TDM (1053-815-653 series). The presence of the (22:0/14:0-18:0/14:0)-TDM and (22:0/ 16:0-18:0/12:0)-TDM isomers are in agreement with the assignment of 18:0/14:0-22:0/14:0- and 18:0/12:0-22:0/ 16:0-TDM isomers as described earlier.

Further dissociation of the ion of $\mathrm{m} / z 1025(1378 \rightarrow 1025)$ (data not shown) gave rise to ions at $m / z 843$ and 815 , which yielded ions of $\mathrm{m} / \mathrm{z} 681$ and 653 , respectively, by loss of glucose (loss of $162 \mathrm{Da}$ ). Structural information from $\mathrm{MS}^{5}$ on the ions of $\mathrm{m} / \mathrm{z} 681(1378 \rightarrow 1025 \rightarrow 843 \rightarrow 681)$ and of $\mathrm{m} / \mathrm{z}$ $653(1378 \rightarrow 1025 \rightarrow 815 \rightarrow 653)$ (not shown) readily gave structural assignments of (24:0/12:0-18:0/14:0)- and (24:0/ 14:0-18:0/12:0)-TDM isomers.

Collectively, the above results demonstrate that the ion at $\mathrm{m} / \mathrm{z}$ 1378 represents major isomers of (18:0/16:0-20:0/14:0)-, (18:0/ 16:0-18:0/16:0)-, and (20:0/14:0-20:0/14:0)-TDM as well as minor (18:0/14:0-20:0/16:0)-, (18:0/12:0-22:0/16:0)-, (18:0/ 14:0-22:0/14:0)-, (20:0/12:0-20:0/16:0)-, (22:0/12:0-18:0/ 16:0)-, (22:0/12:0-20:0/14:0)-, (22:0/14:0-18:0/14:0)-, (22:0/ 14:0-20:0/12:0)-, (24:0/12:0-18:0/14:0)-, and of (24:0/14:0 18:0/12:0)-TDM isomers.

The number of the isomeric structures became even more enormous for the species that possesses unsaturated bond(s). For example, more than 24 isomers were identified for the ion of $m / z 1404$ (Table S2). These isomers varied in the chain lengths of the meromycolate and $\alpha$-branch residues, as well as in the location of unsaturated bond at meromycolate or $\alpha$-branch. The mass spectra obtained by LIT MS ${ }^{n}$ and the description of structural assignments of the ion of $\mathrm{m} / \mathrm{z} 1404$ are appendixed in Supplementary Material (Figure S4 and the text entitled "Structural assignments of the $[\mathrm{M}+\mathrm{Na}]^{+}$ ion of $m / z 1404$ by LIT MS ${ }^{n \prime \prime)}$.

\section{Characterization of TMM as the $\left[\mathrm{M}+\mathrm{CH}_{3} \mathrm{CO}_{2}\right]^{-}$ or $\left[\mathrm{M}+\mathrm{HCO}_{2}\right]^{-}$Ions}

The $\left[\mathrm{M}+\mathrm{CH}_{3} \mathrm{CO}_{2}\right]^{-}$adduct ion of TMM at $\mathrm{m} / z 907$ (Figure S1a) and the $\left[\mathrm{M}+\mathrm{HCO}_{2}\right]^{-}$adduct ion at $\mathrm{m} / z 893$ correspond to the $[\mathrm{M}+\mathrm{Na}]^{+}$ion at $m / z 871$ (Figure 1a). The $\mathrm{MS}^{2}$ spectra of the ions at $\mathrm{m} / \mathrm{z} 907$ (Figure 4a) and at $\mathrm{m} / \mathrm{z} 893$ (data not shown) are nearly identical and contained the ion at $\mathrm{m} / \mathrm{z} 847$ representing a $[\mathrm{M}-\mathrm{H}]^{-}$ion arising from loss of the $\mathrm{CH}_{3} \mathrm{CO}_{2} \mathrm{H}$ or $\mathrm{HCO}_{2} \mathrm{H}$ component. The spectrum (Figure $4 \mathrm{a}$ ) is dominated by the 16:0- and 14:0-acyltrehalose anions at $\mathrm{m} / \mathrm{z} 579$ and 551, arising from loss of $\mathrm{CH}_{3} \mathrm{CO}_{2} \mathrm{H}$, followed by elimination of a octadecanal or an eicosanal residue; while the ions at $m / z 341$ and 323 represent the deprotonated trehalose and [trehalose $\left.-\mathrm{H}_{2} \mathrm{O}\right]^{-}$anions, respectively. The results are in agreement with the earlier structure assignment of 18:0/16:0-TMM and 20:0/14:0-TMM deduced from the $[\mathrm{M}+\mathrm{Na}]^{+}$ion of $m / z 907$. The ion at $m / z 829$ arose from 

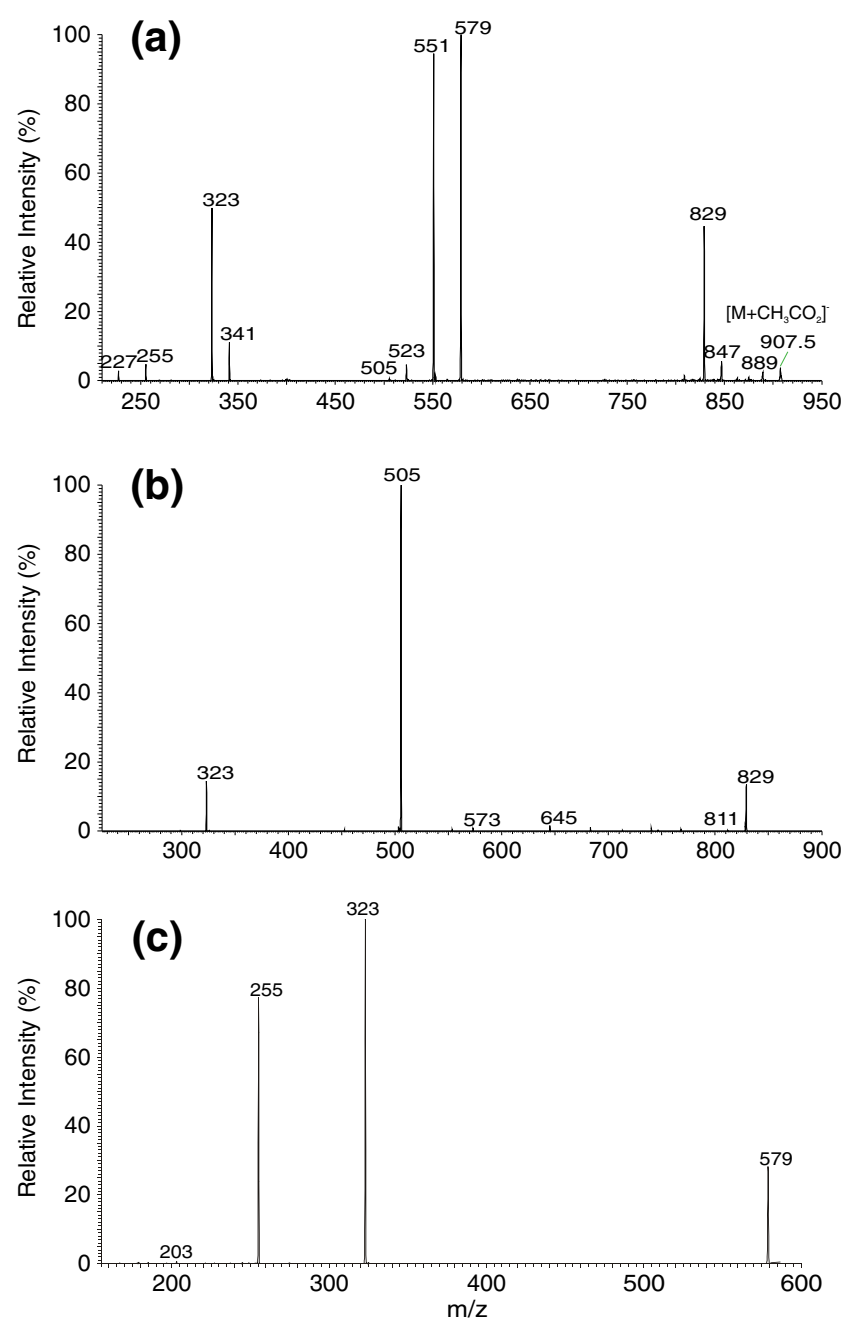

Figure 4. The LIT MS ${ }^{2}$ spectra of the $\left[\mathrm{M}+\mathrm{CH}_{3} \mathrm{CO}_{2}\right]^{-}$ion of TMM at $m / z 907$ (a), its $\mathrm{MS}^{3}$ spectra at $m / z 829$ (907 $\left.\rightarrow 829\right)$ (b), and at $m / z 579(907 \rightarrow 579)$ (c)

loss of $\mathrm{H}_{2} \mathrm{O}$ and gave rise to the dehydrated mycolic acid anion of $m / z 505$ by loss of trehalose (loss as [trehalose $\mathrm{H}_{2} \mathrm{O}$; $\left.324 \mathrm{Da}\right)$. The $\mathrm{MS}^{3}$ spectrum of the ion at $\mathrm{m} / \mathrm{z} 829$ $(907 \rightarrow 829$; Figure 4 b) contained the ions at $\mathrm{m} / \mathrm{z} 505$ and 323 , consistent with the fragmentation process. Further dissociation of the ion of $\mathrm{m} / \mathrm{z} 579(907 \rightarrow 579$; Figure $4 \mathrm{c})$ yielded ions at $\mathrm{m} / \mathrm{z} 323$ ([trehalose $\left.-\mathrm{H}_{2} \mathrm{O}\right]^{-}$) and $\mathrm{m} / \mathrm{z} 255$ (16:0-carboxylate anion), confirming that the ion at $\mathrm{m} / z 579$ represents a deprotonated 16:0-acyltrehalose anion. The results are in agreement with the assignment of the 18:0/ 16:0-TMM isomer. The $\mathrm{MS}^{3}$ spectrum of the ion at $\mathrm{m} / z 551$ $(907 \rightarrow 551$; data not shown) contained ions at $\mathrm{m} / \mathrm{z} 323$ ([trehalose $\left.-\mathrm{H}_{2} \mathrm{O}\right]^{-}$) and 227 (14:0-carboxylate anion), consistent with the presence of 20:0/14:0-TMM. In Figure $4 \mathrm{a}$, a minor ion at $\mathrm{m} / \mathrm{z} 523$ is also present. The $\mathrm{MS}^{3}$ spectrum of the ion of $\mathrm{m} / z 523(907 \rightarrow 523$; not shown), contained ions at $\mathrm{m} / \mathrm{z} 323$ ([trehalose $\left.-\mathrm{H}_{2} \mathrm{O}\right]^{-}$) and 199 (12:0-carboxylate anion), suggesting the presence of the minor 22:0/12:0-TMM isomer. The observation of the 16:0- and 14:0-carboxylate anions at $m / z 255$ and 227 as seen in the in the $\mathrm{MS}^{2}$ (Figure 4a) and $\mathrm{MS}^{3}$ (Figure $4 \mathrm{c}$ ) spectra provides useful information for assignment of the $\alpha$-branch. In contrast, the fragment ions of sodiated acylglucose (i.e., ions at $\mathrm{m} / \mathrm{z} 441$ and 413) that defined the $\alpha$-branch are of low abundance in the $\mathrm{MS}^{\mathrm{n}}$ spectra of the $[\mathrm{M}+\mathrm{Na}]^{+}$ions of TMM and TDM.

Characterization of TDM as $\left[\mathrm{M}+\mathrm{CH}_{3} \mathrm{CO}_{2}\right]^{-}$Ions (the Related Figures are Presented as Supplementary Material Figure S5)

The LIT $\mathrm{MS}^{2}$ spectra of the $\left[\mathrm{M}+\mathrm{CH}_{3} \mathrm{CO}_{2}\right]^{-}$ion at $\mathrm{m} / z$ 1414.1 (Figure $\mathrm{S} 5 \mathrm{a}$ ) and of the $\left[\mathrm{M}+\mathrm{HCO}_{2}\right]^{-}$ion at $\mathrm{m} / \mathrm{z}$ 1399.9 (not shown) are nearly identical. The spectrum (Figure S5a) contained ions at $\mathrm{m} / \mathrm{z} 1354$ arising from loss of $\mathrm{CH}_{3} \mathrm{CO}_{2} \mathrm{H}$, at $\mathrm{m} / z 1085$ arising from further loss of an octadecanal residue, and at $m / z 1067$ (1085 - $\mathrm{H}_{2} \mathrm{O}$ ) arising from additional loss of $\mathrm{H}_{2} \mathrm{O}$. The ions at $\mathrm{m} / z$ 1057 (1354 $\left.\mathrm{C}_{19} \mathrm{H}_{39} \mathrm{CHO}\right)$ and $1039\left(1057-\mathrm{H}_{2} \mathrm{O}\right)$ arose from the analogous losses involving an eicosadecanal residue. Further dissociation of the ion at $\mathrm{m} / z 1067(1414 \rightarrow 1067$; Figure S5b) yielded ions at $m / z 839$ (loss of 14:0-fatty acid) and 811 (loss of 16:0-fatty acid), which gave rise to ions of $\mathrm{m} / \mathrm{z}$ 533 and 505, respectively, by loss of the sugar moiety (loss as [trehalose $-2 \mathrm{H}_{2} \mathrm{O}$ ]). These fragmentation processes were supported by $\mathrm{MS}^{4}$ on the ion at $m / z 839$ (not shown), which yielded prominent ion at $\mathrm{m} / z$ 533, and by $\mathrm{MS}^{4}$ on the ion at $m / z 811(1414 \rightarrow 1067 \rightarrow 811$; Figure S5c), which is dominated by the ion at $\mathrm{m} / z$ 505. The results indicate the molecule consists of both a 18:0/14:0- and a 18:0/16:0mycolyl groups. The ion of $m / z 533\left(551-\mathrm{H}_{2} \mathrm{O}\right)$ represents a deprotonated anion of the dehydrated mycolic acid of $\mathrm{m} / \mathrm{z}$ 551, which consists of both a 20/16:0- and a 22:0/14:0mycolyl groups, as revealed by the $\mathrm{MS}^{3}$ spectrum of the ion at $m / z 551(1414 \rightarrow 551$; data not shown). These results led to assignment of the structures of 18:0/14:0-20:0/16:0 and 18:0/14:0-22:0/14:0-TDM (1413-1067-839-533 series). The ion at $m / z 505\left(523-\mathrm{H}_{2} \mathrm{O}\right)$ also represents a dehydrated mycolic acid anion of $m / z 523$ arising from 18:0/16:0- and 20:0/14:0-mycolic acids. This information gave assignment of 18:0/16:0-18:0/16-TDM and 18:0/16:0-20:0/14:0-TDM (1413-1067-811-505 series).

Further dissociation of the ion of $m / z 1039(1414 \rightarrow 1039$; Figure S5d) gave rise to ions at $m / z 839,811$, and 783 , arising from losses of 12:0-, 14:0-, and 16:0-fatty acids, respectively. These results indicate the molecule consists of 20:0/12:0-, 20:0/14:0-, and 20:0/16:0-mycolyl residues. The ions of $m / z 533\left(551-\mathrm{H}_{2} \mathrm{O}\right), 505\left(523-\mathrm{H}_{2} \mathrm{O}\right)$, and $477(495-$ $\mathrm{H}_{2} \mathrm{O}$ ) are the dehydrated mycolic acid anions arising from ions at $m / z 839,811$, and 783 , respectively, by loss of trehalose residue (loss of [trehalose $-2 \mathrm{H}_{2} \mathrm{O}$ ) (data not sown). These ions bear the similar isomeric structures as described earlier. These structural information gave assignment of 20:0/12:0-20:0/16:0 and 20:0/12:0-22:0/14:0-TDM (1414-1039-839-533 series), 20:0/14:0-18:0/16:0, and 20:0/ 14:0-20:0/14:0 (1414-1039-811-505 series), and 20:0/16:0- 
18:0/14:0, 20:0/16:0-16:0/16:0, and 20:0/16:0-20:0/12:0 (1414-1039-783-477 series). The observation of the 18:0/ 14:0-22:0/14:0-TDM and 20:0/12:0-22:0/14:0-TDM isomers is also consistent with the presence of the ion at $\mathrm{m} / \mathrm{z}$ 1011 arising from elimination of the 22:0-meromycolate chain, in the $\mathrm{MS}^{2}$ spectrum of $\mathrm{m} / \mathrm{z} 1414$ (Figure S5a). The observation of the 18:0/14:0-20:0/16:0-TDM (1414-1067839-533 series) and 20:0/12:0-20:0/16:0-TDM (1414-1039839-533 series) is also consistent with the assignment of 20:0/16:0-20:0/12:0-TDM (1414-1039-783-477 series) and 20:0/16:0-18:0/14:0-TDM (1414-1039-783-477 series) as described earlier.

The ions at $m / z$ 817, 789, 761, and 733 (Figure S5a) are the deprotonated 6,6'-diacyltrehalose anions arising from cleavages of the meroaldehyde residues on both the mycolyl groups. Further dissociation of ions of $m / z$ 817, 789, 761, and 733 (data not shown) confirms that these ions represent deprotonated 6,6'-dihexadeanoyltrehalose, 6-hexadecanoyl6'-tetradecanoyltrehalose, 6,6'-ditetradecanoyltrehalose (or 6-hexadecanoyl-6'-dodecanoyltrehalose), and 6-tetradecanoyl-6'-dodecanolytrehalose anions, respectively. The results are consistent with the notion that the $\alpha$-branch of the mycolic acid substituents mainly consist of 16:0-, 14:0, and 12:0-fatty acid moieties. The structural assignments, again, are in agreement with earlier assignment derived from $\mathrm{MS}^{\mathrm{n}}$ on the corresponding $[\mathrm{M}+\mathrm{Na}]^{+}$adduct ion of $\mathrm{m} / \mathrm{z}$ 1378 .

\section{Conclusions}

We employed LIT MS ${ }^{n}$ to define the structures of TMM and TDM in the cell envelope of $R$. equi without extensive chromatographic separation and chemical reaction steps. We unveiled the structural diversity of the $R$. equi TMMs and TDMs seen by the presence of whole array of the homologous masses $(\mathrm{m} / \mathrm{z})$ of which each mass contains numerous isomers arising from the variation and permutation of the mycolyl groups on both 6 and 6 positions of the trehalose core (Table S1 and S2), not including the positional isomers that may arise from the differences in the location of double bond(s) along the meromycolate or $\alpha$ alkyl chain. Thus, hundreds of TMM and TDM structures are present in the cell envelope of $R$. equi. We also observed the structural similarity among the mycolic acid, TMM, and TDM. For example, the most prominent TMM ion of $\mathrm{m} / \mathrm{z}$ 871 , and the most prominent TDM ion of $\mathrm{m} / \mathrm{z} 1378$ all contained mainly the 18:0/16:0- and 20:0/14:0-mycolyl residues. These findings are in accord with our previous report that 18:0/16:0- and 20:0/14:0-mycolic acids (seen at $\mathrm{m} / \mathrm{z} 523$ as $[\mathrm{M}-\mathrm{H}]^{-}$) are the most prominent mycolic acid found in $R$. equi. [6], and consistent with the notion that mycolic acids are released by enzymatic hydrolysis of TDM [7]. While ESI LIT $\mathrm{MS}^{n}$ on the $[\mathrm{M}+\mathrm{Na}]^{+}\left(\right.$or $[\mathrm{M}+\mathrm{Li}]^{+}$) ions is readily applicable for structural identification and profiling TMM and TDM, negative-ion $\mathrm{MS}^{n}$ on the $[\mathrm{M}+$
$\left.\mathrm{CH}_{3} \mathrm{CO}_{2}\right]^{-}$(or $\left[\mathrm{M}+\mathrm{HCO}_{2}\right]^{-}$) is also useful for structure assignments and profiling these complex lipids.

\section{Acknowledgments}

The authors acknowledge support for this research by US Public Health Service grants P41-RR-00954, R37-DK34388, P60-DK-20579, P01-HL-57278, P30-DK56341, and Deutsche Forschungsgemeinschaft (SFB 670 [A.H.]).

\section{References}

1. Gigue're, S., Prescott, J.F.: Clinical manifestations, diagnosis, treatment, and prevention of Rhodococcus equi infections in foals. Vet. Microbiol. 56, 313-334 (1997)

2. Prescott, J.F.: Rhodococcus equi: An animal and human pathogen. Clin. Microbiol. Rev. 4, 20-34 (1991)

3. von Bargen, K., Haas, A.: Molecular and infection biology of the horse pathogen Rhodococcus equi. FEMS Microbiol. Rev. 33, 870-891 (2009)

4. Sutcliffe, I.C.: Cell envelope composition and organization in the genus Rhodococcus. Antonie van Leeuwenhoek 74, 49-58 (1998)

5. Sutcliffe, I., Brown, A., Dover, L.: The Rhodococcal cell envelope: Composition, organization, and biosynthesis. Journal 16, 29-71 (2010)

6. Hsu, F.F., Soehl, K., Turk, J., Haas, A.: Characterization of mycolic acids from the pathogen Rhodococcus equi by tandem mass spectrometry with electrospray ionization. Anal. Biochem. 409, 112-122 (2011)

7. Ojha, A.K., Trivelli, X., Guerardel, Y., Kremer, L., Hatfull, G.F.: Enzymatic hydrolysis of trehalose dimycolate releases free mycolic acids during mycobacterial growth in biofilms. J. Biol. Chem. 285, 17380-17389 (2010)

8. Brennan, P.J., Nikaido, H.: The envelope of mycobacteria. Annu. Rev. Biochem. 64, 29-63 (1995)

9. Lemaire, G., Tenu, J.P., Petit, J.F., Lederer, E.: Natural and synthetic trehalose diesters as immunomodulators. Med. Res. Rev. 6, 243-274 (1986)

10. Rhoades, E.R., Geisel, R.E., Butcher, B.A., McDonough, S., Russell, D. G.: Cell wall lipids from mycobacterium bovis BCG are inflammatory when inoculated within a gel matrix: Characterization of a new model of the granulomatous response to mycobacterial components. Tuberculosis $\mathbf{8 5}$, 159-176 (2005)

11. Axelrod, S., Oschkinat, H., Enders, J., Schlegel, B., Brinkmann, V., Kaufmann, S.H., Haas, A., Schaible, U.E.: Delay of phagosome maturation by a mycobacterial lipid is reversed by nitric oxide. Cell Microbiol. 10, 1530-1545 (2008)

12. Indrigo, J., Hunter Jr., R.L., Actor, J.K.: Cord factor Trehalose 6,6'Dimycolate (TDM) mediates trafficking events during mycobacterial infection of murine macrophages. Microbiology 149, 2049-2059 (2003)

13. Spargo, B.J., Crowe, L.M., Ioneda, T., Beaman, B.L., Crowe, J.H.: Cord factor ( $\longmapsto, \longmapsto-T r e h a l o s e$ 6,6'-Dimycolate) inhibits fusion between phospholipid vesicles. Proc. Natl. Acad. Sci. U.S.A. 88, 737740 (1991)

14. Geisel, R.E., Sakamoto, K., Russell, D.G., Rhoades, E.R.: In vivo activity of released cell wall lipids of mycobacterium bovis bacillus calmette-guerin is due principally to trehalose mycolates. J. Immunol. 174, 5007-5015 (2005)

15. Kretschmer, A., Bock, H., Wagner, F.: Chemical and physical characterization of interfacial-active lipids from Rhodococcus erythropolis grown on $\mathrm{N}$-Alkanes. Appl. Environ. Microbiol. 44, 864-870 (1982)

16. Asselineau, J., Lederer, E.: Structure of the mycolic acids of mycobacteria. Nature 166, 782-783 (1950)

17. Asselineau, J., Lederer, E.: Sur la constitution chimique des acides mycoliques de deux souches humaines virulentes de mycobacterium tuberculosis. Biochim. Biophys. Acta 7, 126-145 (1951)

18. Wong, M.Y., Steck, P.A., Gray, G.R.: The major mycolic acids of mycobacterium smegmatis. characterization of their homologous series. J. Biol. Chem. 254, 5734-5740 (1979)

19. Rapp, P., Bock, H., Wray, V., Wagner, F.: Formation, isolation, and characterization of trehalose dimycolates from Rhodococcus erythropolis grown on N-Alkanes. J. General Microbiol. 115, 491-503 (1979) 
20. Fujita, Y., Naka, T., Doi, T., Yano, I.: Direct molecular mass determination of trehalose monomycolate from 11 species of mycobacteria by MALDITOF mass spectrometry. Microbiology 151, 1443-1452 (2005)

21. Fujita, Y., Naka, T., McNeil, M.R., Yano, I.: Intact molecular characterization of cord factor (Trehalose 6,6'-Dimycolate) from nine species of mycobacteria by MALDI-TOF mass spectrometry. Microbiology 151, 3403-3416 (2005)

22. De la Pena-Moctezuma, A., Prescott, J.F.: Association with HeLa Cells by Rhodococcus equi with and without the Virulence Plasmid. Vet. Microbiol. 46, 383-392 (1995)

23. Harvey, D.J., Mattu, T.S., Wormald, M.R., Royle, L., Dwek, R.A., Rudd, P.M.: "Internal residue loss" rearrangement during the fragmentation of carbohydrates derivatized at the reducing terminus. Anal. Chem. 74, 734-740 (2002)

24. Ma, Y.L., Vedernikova, I., Van den Heuvel, H., Claeys, M.: Internal glucose residue loss in Protonated O-Diglycosyl flavonoids upon low- energy collision-induced dissociation. J. Am. Soc. Mass Spectrom. 11, 136-144 (2000)

25. Brull, L.P., Kovacik, V., Thomas-Oates, J., Heerma, W., Haverkamp, J.: Sodium-cationized oligosaccharides do not appear to undergo "internal residue loss" rearrangement processes on tandem mass spectrometry. Rapid Commun. Mass Spectrom. 12, 1520-1532 (1998)

26. Warrack, B.M., Hail, M.E., Triolo, A., Animati, F., Seraglia, R., Traldi, P.: Observation of internal monosaccharide losses in the collisionally activated dissociation mass spectra of anthracycline aminodisaccharides. J. Am. Soc. Mass Spectrom. 9, 710-715 (1998)

27. Hsu, F.F., Turk, J.: Studies on sulfatides by quadrupole ion-trap mass spectrometry with electrospray ionization: Structural characterization and the fragmentation processes that include an unusual internal galactose residue loss and the classical charge-remote fragmentation. J. Am. Soc. Mass Spectrom. 15, 536-546 (2004) 